Archived version from NCDOCKS Institutional Repository http://libres.uncg.edu/ir/asu/

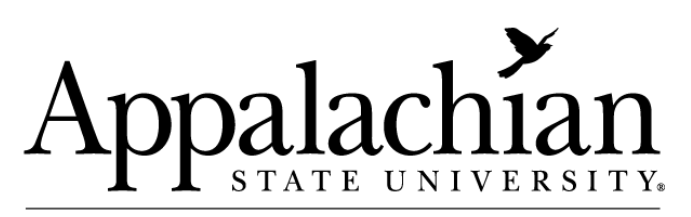

B O O N E, NORTH CAROLI N A

\title{
Views From The "South": \\ Intellectual Hegemony And Postmodernism In Latin America
}

Author: Timothy J. Smith

\begin{abstract}
Euro-American scholars mark Latin America as a site of utopian revolutions, foreign intervention, troubled economies, military repression, and a failed modernist paradigm of development. Four recent books critically assess this construction by addressing its source in the international imaginary. They advocate a subaltern perspective on colonial difference and argue that postmodernity as promulgated by Euro-American scholars may become yet another intellectual trend ignorant of Latin America's particularities and complexities. Latin American scholars have embraced postmodernity far longer than their Euro-American counterparts, whose relatively recent applications remain problematic.
\end{abstract}

Timothy J. Smith (2006) "Views From The "South": Intellectual Hegemony And Postmodernism In Latin America" Reviews in Anthropology \#35 pp.61-78 Version of Record Available @ (DOI. 1080/00938150500535554) 


\section{Views From The "South": Intellectual Hegemony And Postmodernism In Latin America}

\section{Timothy J.Smith}

Hopenhayn, Martin. No Apocalypse, No Integration: Modernism and Postmodernism in Latin America. Durham, NC: Duke University Press, 2001. xix +160 pp.

Lange-Churrion, Pedro and Eduardo Mendieta, eds. Latin America and Postmodernity: A Contemporary Reader. Amherst, NY: Humanity Books, 2001. 317 pp.

Mignolo, Walter D. Local Histories/Global Designs: Coloniality, Subaltern Knowledges, and Border Thinking. Princeton, NJ: Princeton University Press, 2000. xix +371 pp.

Volek, Emil, ed. Latin America Writes Back: Postmodernity in the Periphery (AnInterdisciplinary Perspective). New York: Routledge, 2002. xxviii +282 pp.

Euro-American scholars mark Latin America as a site of utopian revolutions, foreign intervention, troubled economies, military repression, and afailed modernist paradigm of development. Four recent books critically assess this construction by addressing its source in the international imaginary. They advocate a subaltern perspective on colonial difference and argue that postmodernity as promulgated by Euro-American scholars may become yet another intellectual trend ignorant of Latin America's particularities and complexities. Latin American scholars have embraced postmodernity far longer than their Euro-American counterparts, whose relatively recent applications remain problematic.

TIMOTHY J. SMITH is Associate Director, Institute for the Study of Latin America and the Caribbean at the University of South Florida. His research covers the anthropology of politics, ethnicity, democracy, and social movements in Guatemala and Mexico. He is co-editor of The Guatemala Reader and Kaqchikel Maya Authority and Government in Solola. He has published in Ancient Mesoamerica and The Oxford Encyclopedia of Mesoamerican Cultures.

Address correspondence to Timothy J. Smith, Institute for the Study of Latin America and the Caribbean, University of South Florida, 4202 East Fowler Avenue, CPR 107, Tampa, FL 33620, USA. E-mail: smith@iac.usf.edu 
Keywords: Latin America, postmodernism, subaltern studies, Latin American scholars

Throughout the last two decades, the research of many anthropologists working in Latin America has been framed by the social, political, and economic upheavals that have marked a number of countries devastated by armed conflicts, counterinsurgency wars, economic crises, corrupt governments, and foreign intervention. In moves towards peace and reconciliation, however, emerging governments and their foreign aid donors have strategically used the inter- national rhetoric of "democratic transition" and "democratic openings"-many times based on a Euro-American model-as well as focusing on decentralization and the attempt to reconcile multiculturalism with the national project. Included in this process is a celebration of human rights, increased tolerance of ethnic claims, and the challenge of guaranteeing minority rights within a neoliberal framework. Moreover, an emerging acknowledgment of ethnic and cultural diversity is forcing accommodating states to reformulate their definition of citizenship in order to maintain the appearance of their willingness to cooperate in the stable institution of democratic forms of government (Kymlicka 2001).

For nearly forty years, scholars of (and from) Latin America have pointed to the importance and necessity of intellectuals to cover these issues, and to provide an understanding of a region that has been marked by utopian revolutions, foreign intervention, troubled economies, military repression, and a failed modernist paradigm of development. In No Apocalypse, No Integration, Martin Hopenhayn (2001) attempts to lay out what he considers the defining failures of Latin American social planning and the roles of those intellectuals involved with or against the ill-formed models of development narratives. Both utopian movements and the vanguards of development failed to meet the challenges of countries whose populations escaped the violence of war, genocide, and state repression. Instead, they were met with development policy, orthodox Marxism, and dependency theory. However, from the ashes of these paradigms, visions of the Left, and the dismantled state project come new alternatives for social transformation and the creation of new and viable channels for change.

Hopenhayn punctuates the argument by claiming that, while the energies and beliefs in participatory responsibility continue to exist 
in new social movements, albeit fragmented and dispersed at the present, they must be given new meaning in order to survive. Participation in alternative pathways must be relevant and have importance in daily life. The role of the intellectual is not to be abandoned. Rather, intellectuals can make themselves relevant by framing new objects of study in their projects, by making use of Latin America's historical contingencies, and by abandoning the search for any one new paradigm; social scientists must advocate an epistemological pluralism if they are to understand the complexities of post-revolutionary Latin America.

In the 1980s, Latin America witnessed the growth of "financial" capitalism that was not in the least bit productive. While neoliberalism started to expand unbridled, various countries ironically were handed new problems: stagnation of national economies, ineffective and corrupt political systems, and the failure of development policy advocates. The latter is not wholly the fault of domestic deficiencies; global forces and foreign intervention are to blame as well. However, these unexpected failures led to a revision of the role of the state. No longer are governments seen as the driver of the economy or the architects of effective development. This has led to a search for new political alternatives.

One of the more promising moves for everyone has been the revalorization of democracy, through which emerging administrations have acknowledged cultural diversity and have become committed to increasing opportunities for all populations. With an increase in democratic forms of government alongside social fragmentation has come the decentralization of public management. Hopenhayn argues that the crisis of the centralist state as protectorate has shifted political responsibilities and practices into the hands of social movements, public spaces where groups may better express both collective and pluralistic identities of the populations that they claim to represent. These new emerging social movements contain the seeds for alternative social identities and greater participation in legitimate and efficacious forms of government. This is not an easy task, but grassroots movements, popular religion, citizen groups, and other organizations contain the inspiration to initiate alternative development discourses. In their hands rest the future possibilities of Latin America.

In presenting a case of complex political transformations in Latin America, it is interesting that Hopenhayn chooses to present democratic transitions and social movements as clean alternatives to the social agendas of centralist governments in the past. Pondering a "widened secularization" in the future for South America, he 
env1s1ons a greater integration of marginalized groups into the political sphere as an effect of democratization:

The opening of channels of participation to emerging actors would amplify the spectrum of agreement and consequently augment the power of the most marginalized sectors' influence on decisive moments in the formulation of politics. The redistributive struggle would be more equilibrated, without deteriorating the general consensus required to guarantee social peace and political stability. [p. 32]

Moreover, he argues that an increasingly democratic government mixed with the effects of social fragmentation will bring out a much-anticipated decentralization of public management. Is decentralization necessarily a new strategy, one that must be achieved? Per- haps for liberal governments based upon western models. One may look, however, to indigenous communities and see a long and rich tradition of decentralized forms of government, either manifested through continual transformations since the colonial period, or adapted to survive periods of military repression. What of populations that have "fallen back" or revitalized earlier historical forms of decentralization? In the case of multicultural societies, we must ask if decentralization might have been a pre-existing mode of governance for certain groups that now are involved in a renaissance of equity or, rather, that decentralized forms of government have existed in the hinterlands, away from the urban centers, during repressive times and that only now are we acknowledging them. We must ask, decentralization on whose terms? Based upon whose models? To add fuel, might decentralization look like a shadow of illegitimate government juxtaposed with the official government distorted under the pressures of foreign aid and political sanctions?

With respect to social movements, Hopenhayn at times invokes social movements as natural alternatives to centralist governments, as if there has existed free choice in all parts of Latin America. What might an analysis look like if we acknowledge that only now have these choices been possible following the collapse of Leftist planning and the welfare state?

In the middle of the book, he considers new social movements as the "embryos" of alternative socialization. He generalizes their ability to offer new understandings of shared identities and to catalyze a greater democratization of social life. How then does this fit in with a "new" decentralization and move away from the failed centralist models? If, as he states, a fall in central projects led to the rise in 
new social movements, are those local or central movements? Are those regional or national? Provincial or urban? If local, why speak of them as unitary and materializing on a national scale? If central, how and why are they to be considered alternatives to previous centralist modes of organization? What of the rubric of military repression and counterinsurgency wars through which these centralist projects were carried out? I want to believe that he is only speaking of postwar social movements and centralist projects. How many peaceful democratic centralist governments have been given a chance in Latin America (rather, have existed)?

The latter third of the book is devoted to the role of the intelligentsia after their failure to guide social change and the dismantling of their theories, which proved to be anything but relevant to Latin American realities. What is to become of them? What shall be the des- tiny of the intellectual in a time when prescriptive theory has been divorced from realist change? The defeat of state development theorists and utopian predictions has left social scientists with two major concerns. First, the crisis of intelligibility: how will theorists make use of critical thought in their needed search for new epistemologies? How will they attempt to understand the new political and cultural scenarios in Latin America and push beyond older misguided meta- narratives of the 1960s and 1970s (development policy, orthodox Marxism, and dependency theory)? Second, how do intellectuals pro- pose to negotiate the rupture between knowledge production and practical intervention? These are important questions because, according to Hopenhayn, intellectuals in Latin America have justified their place and importance with their ability to contribute to change. However, with the failure of Enlightenment models comes the failure of the social scientist. They must now ask not how their practical intervention may contribute to social change, but how their knowledge production may contribute to social and political change.

In the end, he argues that Latin America must move beyond a paralyzing fatalism and make use of multiple epistemologies. A touch of the Enlightenment and Utopianism must be added to buffer overly pragmatic biases. In addition to tapping society's cultural production, we must also speak of pluralistic societies and acknowledge multiple sites of knowledge production and relevancy. This book is about creation after failure and the challenge to find new forms and strategies for thinking about the future in Latin America.

In his challenging and organic book, Local Histories/ Global Designs, Walter Mignolo (2000) offers thought-provoking solutions for the need to think differently about the postmodern world, and especially about Latin America. In addition to compiling recent 
seminar papers and lectures, this book contains expanded versions of previously published articles. It moves beyond/a mere critique of older paradigms and reconfigures more than a tattered and bruised "straw man" of postmodernity. By exposing the failings of contemporary trends in the social sciences, he charges us with exploring new epistemologies and, rather than simply turning old dichotomies on their head, to question the simplistic polarity of relationships that both the colonial and postcolonial continue to recreate in their engagements. It is not enough to reverse the world and to take on the viewpoint of the subaltern, to expose the myth of cartographies and the destructiveness of metanarratives and the Enlightenment. We must also reconfigure the hierarchies of knowledge into horizontal plains of equal epistemes, to reestablish difference into the shifting grounds of understanding and positionality in the social sciences. The book is dived into three parts: a discussion on the epistemology of postcoloniality, the geopolitics of knowledge, and the languages used in/by cultures and scholarship.

The book opens with the admonition that his concern with challenging current practices and the older paradigms that managed to remain at the end of the twentieth century is influenced by more than a desire to counter the universals of the Enlightenment. He moves beyond the academic satisfaction that colonial and postcolonial dis- course be a new field of study. To engage in these discourses requires scholars to think differently in order to create the condition of possibility for establishing new articulations and areas for understanding. New epistemological vantages are also required to dissuade the pro- motion of mimicry and theoretical exports. Furthermore, academic knowledge must be complemented by other forms of knowledge that may lay outside of traditional registers. Mignolo suggests that one of these new forms of knowledge is border thinking, to think in and from borders, not simply about them. As he terms it, border gnosis encompasses new areas of knowledge and alternative understandings of the world that come from empire's borderlands.

However, border thinking remains elusive without the acknowledgement and understanding of colonial difference. Here Mignolo argues that intellectual projects that seek to level difference (he is far removed from simply talking about universals) are misguided and fail to realize that we must reclaim and reintroduce colonial differences that were repressed and masked during colonial encounters. Border thinking involves much more than understanding and acknowledging colonial difference; it also recognizes that difference from the subaltern perspective, which brings us back to the question of turning poles on end or paradigmatic swapping-it calls for social 
scientists to question the suggestions of both Mignolo and others from the perspective of the subaltern. Otherwise, we fail to escape our own theoretical limitations, thereby recapitulating our commitment to our genealogy, no matter the political expectation. While conceding that border gnosis stems from a subaltern corpus, we must also desubalternize other forms of knowledge in order to advance phenomenological equity. Wanting us to move beyond dichotomies that have been blurred and hybridized, Mignolo suggests that social science expand the horizon of human knowledge by going beyond western and academic concepts of "knowledge," "rationality," and "traditional knowledge" in a move to break colonial distinctions that cast nonwestern forms of knowing aside. He moves on to a discussion of translation, the attempt to absorb difference, as one of the more powerful tools used during colonial encounters. The rest of the book is devoted to language and the topic of translation.

In Chapters 5-7, Mignolo tackles language, imperial constraints, and nation building. His presentation is well informed and brings to light problematic issues that arise from the imposition of a national language upon peoples otherwise to be considered constituents of a pluricultural unit (the nation, nation-state, region, the border, etc.). Mignolo writes of the linguistic maps born of sixteenth and seventeenth centuries, byproducts (albeit necessary) for the segmen- tation and categorization of cultural groups within the imperial project of foreign colonials. If the world is to be now recognized as a fragmented yet interlaced puzzle of previous groupings and cultural maps redrawn, then traditional linguistic maps also are to be redrawn. We may think of the German, Dutch, or English snapshot of geo-cultural memory, which has been cut up; its pieces scattered yet remaining in proximity, begging for a reconstruction.

This re-mapping leads us to "witness a significant switch in the way languages are conceptualized in relation to both colonial control and national ideologies, on the one hand, to knowledge and reason, on the other" (p. 219). Mignolo's invocation of coloniality and the power relations legitimized through archaic linguistics maps and the imposition of national, official, and/ or colonial languages is interesting. Given that the dominant group's control over the cultural production and language of a subaltern population has been made possible through the colonial project, the powerful are left with the cause and ability to create and disseminate their own version of another culture's history and representation.

Something that troubled me, from start to finish, was Mignolo's extreme desire to re-emphasize the dichotomous relationship between central powers (with internal borders) and those neighboring groups 
that were subjugate to the colonial ordering of things, and whose estrangement continues today in the guise of neocolonialism or processes of globalization the re-carving of the pie for the desire and inherent marketability that "strange new lands" have for corporate "enterprises." Consider, for example, "If nation-states are no longer conceived in their homogeneity, if production of commodity is no longer attached to one country, then we should no longer conceive Confucian or Protestant ethics or Native American religions as homogenous systems either" (p. 8).

Why then does Mignolo refer to the "Maya," the "Aymara," the "Quechua," both in his writing of cultural groupings as well as linguistic? I cannot understand how someone that is quick to redraw, emphasize, and bring to light borders and "colonial difference" would choose to ignore those differences that exist within the artificial creation of these groups. He speaks of "languages suppressed under the banners of the nation, such as Quechua and Aymara in Bolivia, and Nahuatl and Maya in Mexico and Central America" (pp. 247-248), as if they were of the homogenous consistency that he argues against. He appears at times to create-rather, reuse-traditional categories of ethnicity and language, yet at other times to argue against the dichotomization process, the Victorian game of naming and boxing.

Perhaps he is unsure of smaller groupings and internal native divisions. Or, perhaps it might complicate or impede the acceptance of his current project. In either case, any faults my meandering nitpicking may find are forgiven, given his far more important engagement. In sum, Walter Mignolo insists that one of the aims of post/ occidental/colonial theorizing is to include moments, events, and other forms of thinking that were repressed and silenced by "modern" reason (p. 110). He advocates a breaking of modern epistemes, to do more than simply replace subject matters as if they were elements of crude grammars. Rather, our projects should include an alternative subject, one that is constituted by a discourse from and about borders (pp. 119-126). If not, we simply reinvigorate an already existing paradigm with new subjective fads; rather than questioning the foundations upon which were built old colonial forms of thinking, we risk remasking the older outdated subjects of analysis. Furthermore, Mignolo reminds us that we cannot discuss reason(s) or the construction of identity without a holistic discussion of gender and sexual relations, nationalisms, religious ideologies, ethnicity, and hierarchies. Located within a reformulated space of political discourse, these other locations may aid in suturing the divide between colonial and postcolonial knowledge(s), rather than filling in the gaps with a removable paste. 
In the edited volume, Latin America and Postmodernity: A Contemporary Reader, Pedro Lange-Churrion and Eduardo Mendieta (2001) have brought together some of the brightest and most progressive scholars from Latin America with respect to the issue of postmodernism (for them, postmodernity) and its various forms. Indeed, they agree with the other books reviewed in this essay that Latin America has undergone significant changes not only in the past thirty years, but over the past five hundred years. The major contribution of this book, however, is the argument that postmodernism was a topic of debate and concern for Latin American scholars long before North American academics started to apply their version to Latin America. Rather than adding to a list of responses and critiques, scholars from Chile, Argentina, Guatemala, Mexico, Cuba, Venezuela, and Colombia have been actively molding postmodern currents and straddling the relationship between "postmodernism" and "Latin America." While they are critical of "the eurocentrism that underpins the postmodern debate," their goal is to complicate these two concepts. What is postmodernism? What is Latin Ameiica?

Like Walter Mignolo's book (he is also a contributor), these essays wish to push the validity of cartographies and western reasoning, to underscore the dark epistemological link between colonialism and the understanding of what Latin America is (or is not). In the introduction, Mendieta reminds those engaged in the postmodern debate:

Latin America is not supplemental or external to (Post)modernity. Instead, it is integral to it. Neither can be thought of without the other. Our conjunctive in the title is less a connective and more an elucidation of an analytical dimension of (Post)modernity. In other words, there is a correspondence between (Post)modernity and Latin America in as much as they are both projects and conditions. [p. 14]

He goes on to comment on the misperception that postmodernity has arrived "late" to Latin America or that scholars are just now picking up on the fashionable trends that dot the Euro-american intellectual landscapes. Rather, Latin America has continued to remain at the heart of postmodernity and its various /-isms/. While it may be argued whether nor not Latin America is postmodern, the notion that requires the larger audience and support is that postmodernity is Latin American. And, lest we forget the negation of understanding between concepts, the idea of the postmodern will continue to be contingent upon the understanding of modernity. Where Latin America 
figures politically and economically in history will hold currency over what we consider "modern" and, consequently, "postmodern."

This book paints the same potentially bleak landscape as Hopenhayn, that Latin America is a site of failed revolutions, economic decline, corrupt governments, a dead Marx (whose spectre remains at large), and the collapse and fragmentation of the Left as a vehicle for social transformation. However, rather than push the positive outlook and recognition of the possible as Hopenhayn does, the authors of this volume make the case that even these and other stereotypes of Latin America must come from Latin America, whose scholars reserve the right to present and analyze the current crises. It must come from within and sit with equity at the side of Euro-American analysis. If, as many of these scholars and those from the following book reviewed in this essay, edited by Emil Volek (2002), contend, if Latin America either remains, is kept, or chooses to remain "the periphery," then Latin American scholars must be allowed to speak. In line with Mignolo's plea for border gnosis and other forms of knowledge, scholars from Latin America are presenting other epistemologies that North America can no longer marginalize if it is to remain faithful to its tenets of postmodernism, thirst for understanding, and the bylaws of political correctness.

Of the collected essays, I found the most interesting and provocative to be from part two of the book. These essays provide alternative conceptions of postmodernism that may oppose EuroAmerican understandings, most notably those by Enrique Dussel (pp. 93-121), Santiago Castro-Gomez (pp. 123-154), Ofelia Schutte (pp. 155-176), and Walter Mignolo (pp. 177-209). In the third part, one of the more enlightening essays, at least for anthropologists, is that of Nelly Richard (pp. 275-289).

Dussel's argument centers on the normativity of modernity and how scholars must rethink their outright rejection of it. He wants to highlight the positive aspects of modernity through a critical examination of its economic and historical contexts, particularly the subordination of the New World by colonial Europe. Rather than pursuing an extreme postmodern view of the events of and after 1492, which may only further the dark crimes of modernity (which, he argues, cannot be glossed over), he wants scholars to retain the critical voice of postmodernism that keeps European universals in check, and refrain from the paralyzing and totalizing discourses that cast aside all of modernity as a construction. Including a critical examination of world systems theory, his article reminded me of the classic arguments of Eric Wolf (1982) and Sidney Mintz (1985). 
Both Castro-Gomez and Schutte tackle the concept of postmodernity and its interpretations from a Latin American context. Castro- G6mez focuses on what he sees as "cliches" of postmodernity- the end of modernity, the end of history, the death of the subject, and the end of utopia-and argues that alternative views exist where these are discredited. There are new histories and new utopian visions, those that do take into account difference and Otherness, and his understandings of these new variants have the balancing flavor of alternatives that make Mignolo's and Hopenhayn's books optimistic rather than hypocritical negations of previous paradigms. What comes from the exposure of these cliches rests in the hands of new modes of critical scholarship. Schutte, on the other hand, examines the Latin American context of postmodernity and stresses the necessary but shifting constructions of identity. She provides an in-depth discussion of strategic identities and the flexibility of transformative discourses, especially those that contest colonial hegemonies and universal essentialisms. Walter Mignolo's essay can be read as an extended summary of his book (reviewed in this essay). Arguably among the most adamant critics of Euroamerican postmodernism, Nelly Richard deconstructs the marginalizing undercurrents of exported Feminism and postmodernism yet markets their reconstitution from a Latin American standpoint, as a strategic use (or rather, intentional misuse) of postmodern theories for consumption by Latin American scholars. This is a diverse book that brings together multiple and interdisciplinary viewpoints, not to dispel postmodernism, but instead to reframe it within and from a Latin American perspective. For that it is highly recommended. However, for those readers agitated by the occasional misspelling, typos, irritable font, and missing references, this book will prolong the reading-which, in the end, might be a good thing.

Latin America Writes Back, edited by Emil Volek (2002), is a powerful testament to the often overlooked engagement which Latin American scholars have with postmodernity and postmodernism. It is a more radical critique of Euro-american postmodernism than the Lange-Churri6n and Mendieta volume and will most certainly meet the North American reader with contempt and combativeness. On the positive side, however, it should serve as a provocative intervention into the at-times marginalizing European/US discussion of subalternity, power, and representation. Volek has gathered a group of scholars from literary criticism, sociology, poetry, journalism, theater, art criticism, urban studies, and history. These authors agree that Latin America has undergone important changes in the past fifty years, including the intellectual upheaval of the 1960s, the economic 
crises of the 1970s, and most especially the neoliberal incursions following the end of the Cold War and the subsequent failure of the Left to promote effective change in Latin American countries torn by military repression, revolution, and economic instability. Indeed, we are living in an era of postmodernity according to these essays, but the contemporary discourses and popular modes of discussion with which we use to describe the cultural and semiotic complexitiesnamely, postmodernism-have mainly been shaped by scholars from Europe and the United States. Volek and company criticize foreign scholars for creating yet another misguided and fanciful intellectual trend which, ironically, chooses to remain ignorant of the particularities and complexities of Latin America. In the introduction, the editor serves up:

While the avant-garde U.S. academic criticism has continued to spin out serial fables about the "Third World," "dependency," "subalternity," and other typically modern intellectual constructs, the illiterate and barefoot wetbacks, undocumented "aliens," and exiles running from the mayhem in their countries has effected a sort of "reverse conquest" of significant bits of "empire" and, in the process, have changed it as well as their original countries, though not always for the better (Take, for example, the Los Angeles-style gang activity brought to Central America by deported emigre youths). [p. xii]

This collection is ultimately a response by Latin American intellectuals to foreign analysts in order to overcome the marginalization of their voices and experiences. The book serves two functions: it attempts to correct the misconceptions that scholars from Europe and the United States perpetuate and second, it offers an understanding and conceptualization of postmodernism from a Latin American perspective. Like Hopenhayn, these authors concede that the Left lacks a viable economic project and this, combined with its political disappointments, has seriously eroded its credibility. However, rather than emphasizing the domestic economic and political particularities that have had such a large impact on the indeterminacies of new social movements, these critics sidestep possible solutions to current crises and choose instead to focus upon foreign intervention and intellectual hegemony.

In a particularly damning statement, the editor accuses US academics for being too "tributary to its own local," for choosing not to acknowledge or respond to new Latin American formations, and criticizes an initial wave of scholars from Latin America during 
the 1990s for being mimetic of North American intellectual trends. Moreover, Volek expels in the same breath his contempt for the United States' flavor of cultural studies which, in his view, has "little to do with culture per se." This is expanded in the essays of Mario Roberto Morales (pp. 123-157) and Armando Silva (pp. 158-171), who present their own leftist positions on culture, and Jorge Larrain (pp. 79-104) and Jesus Martin Barbero (pp. 32-56), who lean towards cultural studies of the British sort. If citing (rather, sighting) cultural studies in the US and postmodernism in general from North America were not enough, he also takes aim at the influence of the South Asian Subaltern Studies Collective of the 1980s on Latin American studies in the United States (see Rodriguez 2001), particularly the rise of concepts such as "subaltern," "post-coloniality," "empire," and the "postcolonial" in the scholarship about Latin America, and critiques both the North American academics who introduced it and scholars from Latin America who followed suit. In the end, he wants to present an avenue for Latin American critics to divulge their own conceptions of Latin America and postmodernism by discussing what they understand as the defining hybrid of modem and premodern identities. After the initial dismissal of European and North American conceptions, there are some interesting chapters that spur reflection. Among the more notable are those by Jesus Martin Barbero (pp. 32-56), Fernando Ainsa (pp. 59-78), Jorge Larrain (pp. 79-104), and Raul Bueno (pp. 189-201), who attempt to reconcile the larger postmodern debates with changing and multiple Latin American identities, all the while struggling to view modernity and postmodernity from the periphery and their guises across internal "borders"-geographical, political, ethnic, and temporal.

Martin Barbero argues that one of the major problems in understanding Latin America has been the insistence of scholars on comparison, of looking "south" from the "northern" vantage point and asking what Latin America looks like from a North American understanding of Modernity. Interestingly enough, this is what Walter Mignolo, a member of the Latin American Subaltern Studies Group, implores us to do in his book. Barbero also presents an interesting case for a pluralist communication that, rather than a "deceptive pluralism that confuses diversity with fragmentation," celebrates "heterogeneity as a value that can be articulated for the construction of a new collective fabric" (p. 54).

In his essay "The Challenges of Postmodernity and Globalization: Multiple or Fragmented Identities?", Fernando Ainsa discusses the crisis of identity in Latin America. He iterates the impossibility of identifying culture solely through texts, rituals, symbols, or objects. 
Given that no system can be organically contained, scholars of and from Latin America must continue to resist stereotyping the "Latin American" and dispel the discourse of homogeneity, which lurks in the writings from abroad. As passe as his critiques may sound, he goes into an oft forgotten-rather, taken for granted-discussion of the origins of Latin American national identities in general. He presents a prescriptive case of belonging, in which people traditionally based their identity upon a national territory correlated with the state, where populations forged a shared identity through a nationalism laced with objects with which they could distinguish themselves from others and find security in belonging to a group. In a postmodern age, however, given the transnational flows of people and goods, exchanges of electronic information over the internet, and the uprooted mobility of students, businesspersons, and laborers, the old categories of collective belonging have been displaced by an individual dimension that has become "characterized by the increasing mobility of a contemporary lifestyle more and more liberated from both biological and social organic dependencies, as well as territorial limitations and historical constraints" (p. 60). However, rather than do away with the notion of community all together, Ainsa speaks of the crisis with an "ontology of belonging," which requires us to reformulate our idea of community. Analysts must look to the periphery and the marginal to locate these new communities. However, that periphery lies not outside the metropolis, the great urban centers, but within. Cosmopolitan centers are the new sites for locating multicultural society in which new formulations of identity are being created.

In light of contemporary issues that include indigenous rights, land and labor issues, questions of representation, multiculturalism, the crisis of identity, and other proxies for influence in Latin America, these are inquiries that have long received attention by scholars in Latin America (Calderon 1986; Martin Barbero 2002:46--54; Garcia Canclini 1990, 1995; Monsivais 1992; Rama 1985; Ortiz 2000). These scholars have been asking, are these transitions not universal in nature? If the answer is no, how do we qualify political and economic transformations and, subsequently, how do they shape and color identities, and vice versa, shifting in a postmodern Latin America? What role do we assign to new social movements when studying regime change and moves towards peace in post-Cold War Latin America?

Contrary to the critiques leveled by the two edited volumes (most especially that of Emil Volek's introduction), I would argue that these questions are being answered in the North American academy by Latino/a and non-Latino/a scholars. Recent ethnographies and 
critical interdisciplinary examinations of Latin America have turned to a discussion of these concepts in order to problematize exactly what the conditions are for their emergence. More important, especially to anthropology recently, has been the location of shifting articulations of multiculturalism and identity, citizenship and ethnic rights, democracy and alternative modes of government, and the discursive formations of these processes (Caldeira 2002; Eckstein and Wickham-Crowley 2003a; Gutmann 2002; Maybury-Lewis 2002; Nelson 1999; Paley 2001; Stephen 2002; Van Cott 2000; Warren and Jackson 2003; Yashar 2005). Even new historical studies are paying more careful attention to the sometimes hidden complexities of identity formation, ethnicity, and citizenship (Carey, Jr. 2001; de la Cadena 2000; Grandin 2000; Yashar 1997).

Since the early nineties, these and other questions have been gaining attention in North America, spurred by an increase in the application of critical theory and the intellectual currents of postmodernism to a hemisphere that is arguably the exemplar of postmodernity and its historical circumstances. Furthermore, other recent works have documented the increasing mobility of Latino/as to, from, and within the United States (Goldin 2000). The visually patchy yet increasingly deadly US-Mexican border (Edberg 2004; Martinez 2002), and the changing nature of the "American" city and Latin@ identities (Davila 2001; Davis 2001), are recalling North American scholars back to Latin America, which includes the US-Mexican border, New York, Los Angeles, Texas, Alaska, and Chicago (and everywhere in-between?). The scholars remind us that we must understand these changes in el Norte, as well as to hold onto the baby of cultural nuance now that the bathwater of orthodox Marxism has been thrown out. I consider these books neither "serial fables" nor avant garde mimicry but serious reflections upon inquiries that we all value as necessary to understand Latin America better.

Still, one of the biggest tasks that remain for anthropologists is that of understanding Latin America from a Latin American perspective, to avoid capturing regions and histories within yet another intellectual net, no matter what our ethical concerns or stated convictions. What must drive our understandings of regional events must be the active intertwining of the political with the contingent. Anthropologists have and will continue to problematize theoretical quests and the epistemological baggage that mask cultural and political practices within societies, those whose makeup is constantly transformed and constitutively plural. To what end, and through what means, our journey takes us will continue to be argued, and these four books should keep readers on that path. 


\section{REFERENCES CITED}

Caldeira, Teresa

2002 City of Walls: Crime, Segregation, and Citizenship in Siio Paulo.

Berkeley: University of California Press.

Calderon, Fernando, ed.

1986 Los Movimientos Sociales ante la Crisis. Buenos Aires: CLACSO/UNO.

Carey, Jr., David

2001 Our Elders Teach Us: Maya-Kaqchikel Historical Perspectives.

Xkib'ij kan qate' qatata'. Tuscaloosa: University of Alabama Press.

Davila, Arlene

2001 Latinos, Inc.: The Marketing and Making of a People. Berkeley:

University of California Press.

Davis, Mike

2001 Magical Urbanism: Latinos Reinvent the U.S. City. New York: Verso.

de la Cadena, Marisol

2000 Indigenous Mestizos: The Politics of Race and Culture in Cuzco, Peru,

1919-1991. Durham, NC: Duke University Press.

Eckstein, Susan Eva, and Timothy P. Wickham-Crowley, eds.

2003a Struggles for Social Rights in Latin America. New York: Routledge.

2003b What Justice? Whose Justice?: Fighting for Fairness in Latin America.

Berkeley: University of California Press.

Edberg, Mark C.

2002 El Narcotraficante: Narcocorridos and the Construction of a Cultural

Persona on the U.S.-Mexican Border. Austin: University of Texas Press.

Garcia Canclini, Nestor

1990 Culturas Hibridas. Estrategias para Entrar y Salir de la Modernidad.

Mexico, D.F.: Grijalbo.

1995 Consumidores y ciudadanos. Conflictos multiculturales de la globalizacion. Mexico, D.F.: Grijalbo.

Goldin, Liliana R., ed.

2000 Identities on the Move: Transnational Processes in North America and

the Caribbean Basin. Albany, NY: Institute for Mesoamerican Studies.

Grandin, Greg

2000 Blood of Guatemala: A History of Race and Nation. Durham, NC:

Duke University Press.

Gutmann, Matthew

2002 The Romance of Democracy: Compliant Defiance in Contemporary

Mexico. Berkeley: University of California Press.

Hopenhayn, Martin

2001 No Apocalypse, No Integration: Modernism and Postmodernism in Latin America. Durham, NC: Duke University Press.

Kymlicka, Will

2001 Politics in the Vernacular: Nationalism, Multiculturalism, and Citizenship. Oxford: Oxford University Press. 
Lange-Churrion, Pedro, and Eduardo Mendieta, eds.

2001 Latin America and Postmodernity: A Contemporary Reader. Amherst, NY:

Humanity Books.

Martinez, Ruben

2002 Crossing Over: A Mexican Family on the Migrant Trail. New York:

Metropolitan Books.

Martin Barbero, Jesus

2002 Communications: Decentering Modernity. In Latin America Writes Back:

Postmodernity in the Periphery (An Interdisciplinary Perspective). Emil Volek, ed. Pp. 39-56. New York: Routledge.

Maybury-Lewis, David, ed.

2002 The Politics of Ethnicity: Indigenous Peoples in Latin American States.

Cambridge, MA: DRCLAS Harvard University.

Mignolo, Walter D.

2000 Local Histories/Global Designs: Coloniality, Subaltern Knowledges, and

Border Thinking. Princeton, NJ: Princeton University Press.

Mintz, Sidney

1985 Sweetness and Power: The Place of Sugar in Modern History. New York: Viking.

Monsivais, Carlos

1992 De la cultura mexicana en visperas de! tratado de libre comercio. Mexico:

Nueva Imagen.

Nelson, Diane

1999 A Finger in the Wound: Body Politics in Quincentennial Guatemalaz.

Berkeley: University of California Press.

Ortiz, Renato

2000 From Incomplete Modernity to World Modernity. Daedalus 129(1):

249-260.

Paley, Julia

2001 Marketing Democracy: Power and Social Movements in Post-Dictatorship

Chile. Berkeley: University of California Press.

Rama, Angel

1985 La critica de la cultura en America Latina. Caracas: Biblioteca Ayacucho.

Rodriguez, Ileana

2001 The Latin American Subaltern Studies Reader. Durham, NC: Duke

University Press.

Stephen, Lynn

2002 Zapata Lives!: Histories and Cultural Politics in Southern Mexico. Berkeley: University of California Press.

Van Cott, Donna Lee

2000 The Friendly Liquidation of the Past: The Politics of Diversity in Latin

America. Pittsburgh, PA: University of Pittsburgh Press.

Volek, Emil, ed.

2002 America Writes Back: Postmodernity in the Periphery (An

Interdisciplinary Perspective). New York: Routledge. 
Warren, Kay, and Jean Jackson, eds.

2003 Indigenous Movements, Self-Representation, and the State in Latin America. Austin: University of Texas Press.

Wolf, Eric

1982 Europe and the People without History. Berkeley: University of California Press.

Yashar, Deborah

1997 Demanding Democracy: Reform and Education in Costa Rica and Guatemala. Stanford, NC: Stanford University Press.

2005 Contrasting Citizenship in Latin America; The Rise of Indigenous Movements and Postliberal Challenge. Cambridge: Cambridge University Press. 